\title{
Murskesäilötty ohra sinikettujen rehuna
}

\author{
Jarmo Valaja ${ }^{1)}$, Eija Valkonen ${ }^{1)}$, Eija Venäläinen ${ }^{1)}$, Taina Jalava ${ }^{1)}$, Ilpo Pölönen ${ }^{2)}$ ja Tuula Dahlman ${ }^{2)}$ \\ ${ }^{1)}$ MTT, Kotieläintuotannon tutkimus, Eläinravitsemus, 31600 Jokioinen, etunimi.sukunimi@mtt.fi \\ ${ }^{2)}$ Suomen turkiseläinten kasvattajain liitto ry, PL 5, 01601 Vantaa, etunimi.sukunimi@stkl-fpf.fi
}

\section{Tiivistelmä}

Murskesäilöntä on viljan varastointimenetelmä, jossa vältetään kallis kuivaus. Se on parantanut ohran ruokinnallista arvoa yksimahaisilla, sioilla ja siipikarjalla. Turkiseläimille murskesäilöttyä ohraa ei ole tutkittu. Tämän tutkimuksen tavoitteena oli selvittää murskesäilötyn ohran sulavuus siniketuilla. Lisäksi tutkittiin voidaanko amylaasi-ksylanaasi-3-glukanaasientsyymilisällä tai kypsennyksellä parantaa murskesäilötyn ja kuivatun ohran sulavuutta ja käyttökelpoisuutta ketuille.

Tutkimuksessa oli mukana 24 noin viisi kuukautta vanhaa sinikettu-urosta. Ketut olivat kokeen ajan yksilöhäkeissä, jotka mahdollistivat sonnan ja virtsan erilliskeruun. Koemallina oli cyclic changeover ja koejaksoja oli viisi. Jakson pituus oli yhdeksän päivää, kuusi päivää valmistuskautta ja kolme päivää sonnan keruuta. Kettujen rehu vaihtui aina jakson vaihtuessa.

Kolme tutkittavaa tekijää oli järjestetty kahdeksaan koekäsittelyyn $2 \times 2 \times 2$ faktoriaalisesti. Tutkittavat tekijät olivat:1. viljatyyppi: kuivattu tai murskesäilötty ohra; 2. kypsennys: raaka tai kypsennetty ohra; 3. Entsyymikäsittely: ei entsyymikäsittelyä tai amylaasi-ksylanaasi- $\beta-$ glukanaasientsyymi.

Murskesäilöttävä ohra puitiin elokuussa 2004 ja litistettiin Murska 350S valssimyllyllä. Se säilöttiin AIV 2+-liuoksella (3 1/tn) $1500 \mathrm{~kg}$ pyöreisiin säilörehusiiloihin. Siilot avattiin lokakuun lopussa, kun koerehut valmistettiin. Ohrapuuroja keitettiin 20 min öljyvaippakattilassa. Entsyymikäsittely kesti 16 tuntia huoneen lämmössä. Koerehut sisälsivät tutkittavaa ohraa, hapotettua sikateurassivutuotetta, kalajauhoa, kasviöljyä, vettä, metioniinia sekä vitamiini- ja hivenaineseoksia. Rehut valmistettiin ennen kokeen alkua ja pakastetaan ryhmäkohtaisiin päiväannoksiin. Eläimet ruokittiin kerran päivässä ja ne saivat rehua 700-1100 g/pv.

Murskesäilötty ja kuivattu ohra sisälsivät yhtä paljon ß-glukaaneja, mutta murskesäilötyssä ohrassa oli selvästi vähemmän liukoisia ß-glukaaneja. Entsyymikäsittely ja keitto pilkkoivat ohran tärkkelystä sokereiksi. Entsyymi myös muutti liukenemattomia ß-glukaaneja liukoisiksi.

Siniketut söivät hyvin murskesäilöttyä ohraa, vaikka sitä ei erikseen jauhettu. Ketut kasvoivat yhtä hyvin sekä murskesäilötyllä että tavallisella ohralla. Kasvu oli nopeinta, kun ne söivät kypsennettyä ohraa. Kypsän ohran entsyymikäsittely paransi kettujen kasvua entisestään.

Raa'an murskeohran tärkkelyksen sulavuus oli huonompi kuin kuivatun ohran. Kypsennys ja entsyymikäsittely paransivat murskeohran tärkkelyksen sulavuuden kypsän ja entsyymikäsitellyn tavallisen ohran tasolle. Raa'an tärkkelyksen sulavuus oli alle 50\%, mutta kypsennys ja entsyymikäsittely nostivat sulavuuden yli 80\%:iin. Kokeen tulokset osoittavat, että murskesäilötyn ohran käyttöä voidaan vakavasti harkita myös kasvavien sinikettujen ruokinnassa.

Avainsanat: sinikettu, ohra, murskesäilöntä, keitto, entsyymi, sulavuus 


\section{Johdanto}

Murskesäilöntä on viljan varastointimenetelmä, jossa litistetty kostea vilja säilötään anaerobisesti laaka- tai tornisiiloon. Säilöntätuloksen varmistamiseksi käytetään säilöntäainetta, AIV-liuosta tai biologista säilöntäainetta. Murskesäilönnällä on monia käytännön etuja. Murskevilja on pölytöntä eikä vaadi jauhamista. Murskesäilönnässä myös vältetään kallis kuivaus. Viljan korjuuajankohta on joustavampi ja viljelyssä voidaan käyttää pitkän kasvuajan vaativia satoisia lajikkeita.

Murskesäilöntä yleensä parantaa myös ohran ruokinnallista arvoa yksimahaisilla. Ohran liukoinen kuitu pilkkoutuu säilönnän aikana. Myös ohran fosfori vapautuu sulavampaan muotoon. Murskesäilöntä on parantanut ohran sulavuutta ja rehuarvoa sioilla ja siipikarjalla (Valaja ym. 1999, Perttilä ym. 2001, Venäläinen ym. 2006). Turkiseläimien ruokinnassa murskesäilöttyä ohran käyttöä ei ole tutkittu.

Viimeaikaisissa kokeissa raa'an ohran tärkkelyksen sulavuus siniketuilla on ollut yllättävän huono, mutta kypsennys on selvästi parantanut tärkkelyksen sulavuutta (Valaja ym. 2004). $\beta$ glukanaasientsyymikäsittely ei juurikaan parantanut ohran sulavuutta siniketuilla (Valaja ym. 2004). Viljan tärkkelystä sulattaa amylaasientsyymi, jota voidaan lisätä myös rehun joukkoon. Amylaasin käytöstä turkiseläinten ruokinnassa ei ole kokemusta.

Tutkimuksen tavoitteena oli selvittää murskesäilötyn ohran maittavuus ja sulavuus siniketuilla. Lisäksi selvitettiin voidaanko entsyymikäsittelyllä (amylaasi, ksylanaasi ja ß-glukanaasi) tai kypsennyksellä parantaa murskesäilötyn ja kuivatun ohran sulavuutta ja käyttökelpoisuutta siniketuille.

\section{Aineisto ja menetelmät}

Tutkimuksessa oli koe-eläiminä 24 kasvavaa sinikettu-urosta, jotka olivat kokeen alkaessa noin $5 \mathrm{kk}$ ikäisiä. Koe-eläimiä pidettiin kokeen aikana yksilöhäkeissä $(120 \times 70 \times 70 \mathrm{~cm})$, jotka mahdollistivat sonnan ja virtsan kvantitatiivisen keräämisen. Koepaikkana oli MTT:n eläinravitsemuksen tutkimusalan broilerikasvattamo. Koeaika oli 1.11.-16.12.2004.

Koemallina oli 8x5 cyclic change-over. Ketut jaettiin kolmeen kahdeksan eläimen blokkiin. Kahdeksan koekäsittelyä vaihtui jokaisella jaksolla blokkien sisällä. Kokeessa oli viisi jaksoa. Jokaisen jakson pituus oli yhdeksän päivää. Jakso koostui kuuden päivän valmistuskaudesta ja kolmen päivän sonnan keruukaudesta. Sonta kerättiin kerran päivässä, punnittiin ja pakastettiin.

Kokeessa oli kolme tukittavaa tekijää, jotka oli järjestetty kahdeksaan koekäsittelyyn $2 \times 2 \times 2$ faktoriaalisesti. Tutkittavat tekijät olivat: 1 . viljatyyppi: kuivattu tai murskesäilötty ohra; 2 . kypsennys: raaka tai kypsennetty ohra; 3.entsyymilisä: ei entsyymikäsittelyä tai ohran amylaasi-xylanaasi- $\beta$ glukanaasientsyymikäsittely (Heptex LF, Danisco Animal Nutrition). Entsyymiseos sisälsi ßglukanaasia $375 \mathrm{U} / \mathrm{g}$, xylanaasia $3000 \mathrm{U} / \mathrm{g}$ ja alfa-amylaasia $4000 \mathrm{U} / \mathrm{g}$.

Kahdeksan koeryhmää olivat:

1. Kuivattu ohra

2. Kuivattu entsyymikäsitelty ohra

3. Puuroksi keitetty kuivattu ohra

4. Puuroksi keitetty entsyymikäsitelty kuivattu ohra

5. Murskesäilötty ohra

6. Murskesäilötty entsyymikäsitelty ohra

7. Puuroksi keitetty murskesäilötty ohra

8. Puuroksi keitetty entsyymikäsitelty murskesäilötty ohra

Ohra murskesäilöttiin elokuussa 20041500 kg:n lieriömäisiin koesiiloihin. Ohran jyvät litistettiin ennen säilöntää Murska 350S valssimyllyllä (Aimo Kortteen konepaja Oy, Ylivieska). Säilöntäaine, AIV 2+ (76\% muurahaishappoa) (3 1/tn) laimennettiin vedellä (1:2) ja sekoitettiin ruiskupullolla murskatun ohran joukkoon siilon täytön aikana. Ennen täyttämistä siilot vuorattiin muovilla. Täytön jälkeen siilo peitettiin muovilla ja puukannella. Kansi painotettiin betonipalkeilla. Siilo avattiin lokakuun lopussa, kun koerehut valmistettiin. Kuiva ohra puitiin viikkoa myöhemmin viereiseltä lohkolta ja kuivattiin normaalisti lämminilmakuivurissa. Kuivattu ohra jauhettiin $3 \mathrm{~mm}$ seulalla, mutta murskesäilötty ohra sekoitettiin rehuun sellaisenaan.

Kypsytetty ohrapuuro valmistettiin öljyvaippakattilassa. Keittoaika oli 20 minuuttia. Kuiva ohran seossuhde on $30 \%$ ohraa ja $70 \%$ vettä. Murskeohrapuurossa seossuhde oli $50 \%$ vettä ja $50 \%$ 
ohraa. Entsyymikäsittely tehtiin huoneen lämmössä keiton ja jauhamisen jälkeen ja se kesti 16 tuntia. Annostustaso oli $450 \mathrm{ml}$ entsyymiä/tn ilmakuivaa rehua. Entsyymiä laimennettiin vedellä tasaisen leviämisen varmistamiseksi.

Taulukko 1. Koerehujen raaka-aineet (\%) ja rehujen analysoitu kemiallinen koostumus (g/kg ka).

\begin{tabular}{|c|c|c|c|c|c|c|c|c|}
\hline Rehu & 1 & 2 & 3 & 4 & 5 & 6 & 7 & 8 \\
\hline \multicolumn{9}{|l|}{ Raaka-aineet, $\%$} \\
\hline Sikateurassivutuote & 47,72 & 47,72 & 31,21 & 31,52 & 44,30 & 44,30 & 34,92 & 34,39 \\
\hline $\mathrm{Ohra}^{1}$ & 32,33 & 35,57 & 65,24 & 64,90 & 39,79 & 41,78 & 61,11 & 61,70 \\
\hline Kalajauho & 1,54 & 1,54 & 1,01 & 1,02 & 1,43 & 1,43 & 1,13 & 1,11 \\
\hline STKL-vitamiini & 0,04 & 0,04 & 0,02 & 0,02 & 0,03 & 0,03 & 0,03 & 0,03 \\
\hline Turkishivenseos & 0,62 & 0,62 & 0,40 & 0,41 & 0,57 & 0,57 & 0,45 & 0,45 \\
\hline Rypsiöljy & 3,08 & 3,08 & 2,01 & 2,04 & 2,86 & 2,86 & 2,25 & 2,22 \\
\hline Metioniini & 0,15 & 0,15 & 0,10 & 0,10 & 0,14 & 0,14 & 0,11 & 0,11 \\
\hline Vesi & 14,51 & 11,28 & 0,00 & 0,00 & 10,88 & 8,89 & 0,00 & 0,00 \\
\hline \multicolumn{9}{|l|}{ Koostumus } \\
\hline Kuiva-aine, g/kg & 468,1 & 465,1 & 300,8 & 302,3 & 429,0 & 427,5 & 340,6 & 329,0 \\
\hline Raakavalkuainen & 213,4 & 213,3 & 213,8 & 217,6 & 224,7 & 236,5 & 221,5 & 232,3 \\
\hline Tärkkelys & 374,6 & 370,3 & 356,9 & 352,6 & 378,1 & 319,5 & 368,1 & 358,2 \\
\hline \multicolumn{9}{|l|}{ ß-glukaanit } \\
\hline Kokonais & 16,2 & 10,9 & 15,7 & 13,6 & 18,4 & 13,8 & 18,3 & 14,9 \\
\hline Liukoiset & 7,0 & 9,5 & 4,3 & 12,9 & 5,3 & 8,4 & 3,9 & 12,9 \\
\hline Liukenemattomat & 9,1 & 1,4 & 11,4 & 0,8 & 13,2 & 5,4 & 14,4 & 2,0 \\
\hline
\end{tabular}

1. rehu 1: kuiva ohra; rehu 2: kuiva ja entsyymikäsitelty ohra; rehu 3: kuiva ja keitetty ohra; 4: Kuiva, keitetty ja entsyymikäsitelty ohra; rehu 5: murskesäilötty ohra; rehu 6: murskesäilötty ja entsyymikäsitelty ohra; rehu 7: murskesäilötty ja keitetty ohra; rehu 8: murskesäilötty, keitetty ja entsyymikäsitelty ohra.

Koerehut sisälsivät tutkittavaa ohraa, hapotettua sikateurassivutuotetta, kalajauhoa, kasviöljyä, vettä sekä vitamiini- ja hivenaineseoksia (taulukko 1). Rehut pyrittiin suunnittelemaan siten, että ohran osuus kuiva-aineesta oli kaikissa koerehuissa sama. Kaikki rehut valmistettiin ennen kokeen alkua ja pakastetaan ryhmäkohtaisiin päiväannoksiin. Eläimet ruokittiin kerran päivässä ja ne saivat rehua 700-1100 g/pv. Rehuannos vaihteli rehun analysoidun kuiva-ainepitoisuuden mukaan. Eläimet punnittiin kokeen alussa ja sekä jokaisen keruukauden alussa ja lopussa.

Kokeen tulokset analysoitiin SAS-ohjelmiston GLM-ohjelmalla (SAS 1990). Tilastollisessa mallissa oli mukana blokin(b), ketun (k), jakson (j) ja rehun (r) vaikutukset. Tilastollinen malli oli:

$$
\mathrm{y}=\mu+\mathrm{b}+(\mathrm{k}) \mathrm{b}+\mathrm{j}+\mathrm{r}+\mathrm{n} * \mathrm{r}+\varepsilon .
$$

Ohrakäsittelyiden vaikutukset analysoitiin ortogonaalisilla kontrasteilla: $\mathrm{C} 1$ : säilönnän vaikutus (kuivattu ohra vs murskesäilötty ohra); C2: Kypsennyksen vaikutus (raaka ohra vs. keitetty ohra); C3: ohran entsyymikäsittely vaikutus (ei entsyymiä vs. entsyymi Heptex LF); C4: säilönnän ja kypsennyksen yhdysvaikutus $\left(\mathrm{C} 1{ }^{*} \mathrm{C} 2\right)$; $\mathrm{C} 5$ : säilönnän ja entsyymikäsittelyn yhdysvaikutus $\left(\mathrm{C} 1{ }^{*} \mathrm{C} 3\right)$; C5: kypsennyksen ja entsyymikäsittelyn yhdysvaikutus $(\mathrm{C} 2 * \mathrm{C} 3)$.

\section{Tulokset ja tulosten tarkastelu}

Murskesäilötyn ohran valmistus ja säilöntä onnistuivat hyvin (taulukko 2). Kaikki ohraerät sisälsivät ß-glukaaneja lähes yhtä paljon. Entsyymikäsittely ei alentanut ß-glukaanien kokonaismäärää, mutta se muutti selvästi liukenemattomia $ß$-glukaaneja liukoiseen muotoon. Murskeohra sisälsi enemmän liukenemattomia ja vähemmän liukoisia $\beta$-glukaaneja kuin kuiva ohra. Aikaisemmissa murskesäilöntäkokeissa ß-glukaanien kokonaismäärä on selvästi vähentynyt säilönnän aikana, koska kosteat ja happamat olosuhteet sekä ohran luontaiset ß-glukanaasientsyymit edistävät ß-glukaanien pilkkoutumista (Valaja ym. 1999, Perttilä ym. 2001). Ilmeisesti tässä kokeessa ohran kuivaainepitoisuus säilöntäaikana oli liian korkea ja mikrobifermentaatio jäi vähäiseksi. Murskesäilötyn ohran $\mathrm{pH}$ oli korkeampi ja haihtuvien rasvahappojen sekä maitohapon määrä oli pienempi kuin aikaisemmissa tutkimuksissa (Valaja ym. 1999).

Ohraerien tärkkelyspitoisuus määritettiin kahdella hiukan erilaisella menetelmällä, koska haluttiin selvittää prosessoinnin vaikutuksia tärkkelykseen (taulukko 2). Virallisessa menetelmässä vapaat sokerit uutettiin pois ennen tärkkelyksen pilkkomista sokereiksi ja määritystä. Vaihtoehtoisessa 
menetelmässä tärkkelys määritettiin suoraan ilman vapaiden sokereiden uuttoa. Sokeriuutolla virallisella menetelmällä määritetty tärkkelyspitoisuus oli alhaisin keitetyissä ja entsyymikäsitellyissä ohrissa. Ilman sokeriuuttoa määritetty tärkkelyspitoisuus oli kaikissa ohrissa lähes sama. Ilmeisesti entsyymikäsittely ja keitto pilkkoivat tärkkelystä turkiseläimillä paremmin sulaviksi sokereiksi. Eniten tärkkelys pilkkoutui, kun keiton jälkeen tehtiin entsyymikäsittely. Ilmeisesti keitto rikkoi tärkkelysjyväsiä ja entsyymi pääsi paremmin vaikuttamaan tärkkelyspartikkeleihin.

Koerehujen kemiallinen analyysi osoitti, että entsyymi pilkkoi $\beta$-glukaaneja rehun sekoittamisen jälkeen säilytyksen aikana (taulukko 1). Erityisesti entsyymikäsittely vähensi $\beta$-glukaanien kokonaismäärää sekä muutti liukenemattomia $\beta$-glukaaneja liukoisiksi.

Ketut söivät rehunsa halukkaasti, vaikka murskesäilöttyä ohraa ei erikseen jauhettukaan. Kettujen saama päivittäinen rehumäärä vaihteli 708 grammasta 1095 grammaan, koska kuiva-aineen saanti pyrittiin pitämään samana. Päivittäinen kuiva-aineen syönti olikin kaikissa ryhmissä 330-340 grammaa.

Tärkkelyksen sulavuudessa oli suuria eroja koerehujen välillä (taulukko 3). Käsittelemättömän murskesäilötyn ohran tärkkelyksen sulavuus oli alhaisin (36,1\%). Entsyymikäsittely paransi murskesäilötyn ohran sulavuutta, vaikka sulavuus yhä oli alhainen (41,9\%). Eniten murskesäilötyn ohran tärkkelyksen sulavuutta paransi keittokäsittely, jonka jälkeen sulavuus oli jo 72,6\%. Sekä keiton että entsyymikäsittelyn yhdistämisen jälkeen murskesäilötyn ohran tärkkelyksen sulavuus oli korkein $(82,7 \%)$. Myös keitetyn ja entsyymikäsitellyn tavallisen ohran tärkkelys suli erittäin hyvin $(82,8 \%)$. Käsittelemättömän kuivan ohran tärkkelyksen sulavuus oli selvästi parempi kuin murskesäilötyn ohran $(\mathrm{p}<0.001)$. Kuitenkin sekä keitto että entsyymikäsittely paransivat eniten murskesäilötyn ohran tärkkelyksen sulavuutta. Keitto on parantanut selvästi ohran hiilihydraattien ja tärkkelyksen sulavuutta ketuilla myös aikaisemmissa tutkimuksissa (Kiiskinen ym. 1988, Valaja ym. 2004). ßglukanaasientsyymikäsittely ei kuitenkaan parantanut ohran tärkkelyksen sulavuutta siniketuilla, kun entsyymi lisättiin kylmään valmiiseen rehuun (Valaja ym. 2004). Tässä kokeessa käytetty entsyymi (amylaasi-ksylanaasi-ß-glukanaasi) sekä käsittelyn pituus (16 tuntia) poikkesivat aikaisemman kokeen järjestelyistä. Entsyymin vaikutus sulavuuteen oli positiivinen, koska lämpö sekä aika tehostavat entsyymin vaikutusta. Børstingin ym. (1995) kokeessa ß-glukanaasientsyymikäsittely paransi raa'an sekä keitetyn vehnäpohjaisen rehun sulavuutta minkeillä. Entsyymikäsittely on parantanut ohrapohjaisten rehujen sulavuutta myös koirilla (Twomey ym. 2003).

Murskesäilöttyä ohraa sisältävän rehun valkuaisen sulavuus oli yhtä hyvä kuin kuivattua ohraa sisältävän rehun. Sekä entsyymikäsittely että keitto paransivat hiukan raakavalkuaisen sulavuutta $(\mathrm{p}<0.001)$. Kuivattua ohraa sisältävien rehujen raakarasva sulavuus oli hiukan parempi kuin murskesäilöttyä ohraa sisältävien rehujen $(\mathrm{p}<0.001)$. Entsyymikäsittely paransi hiukan myös raakarasvan sulavuutta, mutta keitolla ei ollut juurikaan vaikutuksia rasvan sulavuuteen. Käsittelyiden vaikutukset rasva ja valkuaisen sulavuuteen olivat kaiken kaikkiaan selvästi pienempiä kuin tärkkelyksen sulavuuteen.

Sulavuuskokeen tulosten perusteella lasketut koerehujen muuntokelpoisen energian (ME) arvot on esitetty taulukossa 3. Tulokseen vaikuttivat sekä koerehujen analysoitu koostumus että ravintoaineiden sulavuus. Huonoin ME-arvo oli raakaa murskesäilöttyä ohraa sisältävällä rehuseoksella (11,91 MJ/kg ka). Paras ME-arvo oli kypsää entsyymikäsiteltyä murskesäilöttyä ohraa sisältävällä rehuseoksella $(15,90 \mathrm{MJ} / \mathrm{kg} \mathrm{ka})$. Erot näiden kahden raaka-ainekoostumukseltaan samanlaisen rehun energia-arvossa oli huimat 3,99 MJ/kg ka. Myös kypsän ja entsyymikäsitellyn kuivatun ohran energia-arvo oli hyvä $(15,75 \mathrm{MJ} / \mathrm{kg} \mathrm{ka})$. Sekä keitto että entsyymikäsittely paransivat rehujen energia-arvoja. Kettujen päiväkasvuerot noudattivat hyvin sulavuuden ja ME-arvojen eroja. Parhaiten kasvoivat ketut, jotka söivät kypsää ja entsyymikäsiteltyä murskesäilöttyä ohraa $(60,9 \mathrm{~g} / \mathrm{pv})$. Myös kypsää ja entsyymikäsiteltyä tavallista ohraa syöneet ketut kasvoivat hyvin $(50,0 \mathrm{~g} / \mathrm{pv})$. Käsittelemättömän kuivan ohran ja murskesäilötyn ohran välillä ei ollut eroja kettujen kasvussa. Kypsennys sekä sen jälkeinen viljan entsyymikäsittely paransivat erityisesti kettujen kasvua.

\section{Johtopäätökset}

Raa'an murskesäilötyn ohran hiilihydraattien sulavuus oli heikko, mutta jatkokäsittelyt, keitto ja entsyymikäsittely paransivat selvästi murskesäilötyn ohran hiilihydraattien sulavuutta. Käsittelyiden jälkeen murskesäilötyn ohran hiilihydraattien sulavuus oli jopa hiukan parempi kuin keitetyn ja entsyymikäsitellyn tavallisen ohran. Keitto paransi hiilihydraattien sulavuutta enemmän kuin 
entsyymikäsittely, mutta käsittelyiden yhteisvaikutus oli tehokkain. Myös keitettyä ja entsyymikäsiteltyä murskesäilöttyä ja tavallista ohraa syöneiden kettujen kasvu oli nopeinta. Kokeen tulokset osoittavat, että murskesäilötyn ohran käyttöä voidaan vakavasti harkita myös kasvavien sinikettujen ruokinnassa.

\section{Kirjallisuus}

Børsting, C.F., Bach Knudsen, K.E., Steenfeld, S., Mejborn, H. \& Eggum, B.O. 1995. The nutritive value of decorticated mill fractions of wheat. 3. Digestibility experiments with boiled and enzyme treated fractions fed to mink. Anim. Feed Sci. Technol. 53: 317-336.

Kiiskinen, T., Mäkelä, J. \& Rouvinen, K. 1988. Eri viljalajien sulavuus minkillä ja siniketulla. Maatalouden tutkimuskeskus Tiedote 5/88, Jokioinen 1988 ISSN 0359-7652 $23 \mathrm{~s}$.

Perttilä, S., Valaja, J., Partanen, K., Jalava, T., Kiiskinen, T. \& Palander, S. 2001. Effects of preservation method and B-glucanase supplementation on ileal amino acid digestibility and feeding value of barley for poultry. Br. Poultry Sci. 42: 218-229.

SAS 1990. SAS/STAT® User's guide, Version 6, Fourth Edition, Volumes 1-2, SAS Institute

Inc., Cary, NC, USA. $1686 \mathrm{p}$.

Twomey, L.N., Pluske, J.R., Rowe, J.B., Choct, M., Brown, W., Mc Connell, M.F. \& Pethick, D.W. 2003. The effects of increasing levels of soluble non-starch polysaccharides and inclusion of feed enzymes in dog diets on faecal quality and digestibility. Anim. Feed. Sci. Technol. 108: 71-82.

Valaja, J., Jaakkola, S., Siljander-Rasi, H., Perttilä, S., Joki-Tokola, E., Huhtanen, P \& Tenhunen, J. 1999. Murskesäilötyn viljan käsittelyteknologia. Loppuraportti 9.12.1999.

Valaja, J., Pölönen, I., Valkonen, E. \& Jalava, T. 2004. Effect of lactic acid bacteria and ß-glucanase treatments on the nutritive value of barley for growing pigs. Scientifur 28: 116-119.

Venäläinen, E., Valaja, J., Valkonen, E. \& Jalava, T. 2006. Murskesäilötty ohra sopii broilereiden rehuun. Maataloustieteen päivät 2006.

Taulukko 2. Eri tavoin käsiteltyjen ohrien kemiallinen koostumus (g/kg ka).

\begin{tabular}{|c|c|c|c|c|c|c|c|c|}
\hline Ohra & Kuiva & $\begin{array}{l}\text { Kuiva+ } \\
\text { ents. } \\
\text { käsittely }\end{array}$ & $\begin{array}{l}\text { Kuiva+ } \\
\text { keitto }\end{array}$ & $\begin{array}{c}\text { Kuiva+ } \\
\text { keitto+ } \\
\text { ents. } \\
\text { käsittely }\end{array}$ & Murskes. & $\begin{array}{l}\text { Murskes. } \\
\text { +ents. } \\
\text { käsittely }\end{array}$ & $\begin{array}{l}\text { Murskes.+ } \\
\text { keitto }\end{array}$ & $\begin{array}{c}\text { Murskes.+ } \\
\text { keitto+ } \\
\text { ents. } \\
\text { käsittely }\end{array}$ \\
\hline Kuiva-aine, g/kg & 862,6 & 790,1 & 279,2 & 295,5 & 657,4 & 638,3 & 345,8 & 338,2 \\
\hline Raakavalkuainen & 111,4 & 110,9 & 112,7 & 112,4 & 132,6 & 135,8 & 133,3 & 130,4 \\
\hline Raakarasva & 25,7 & 28,3 & 28,5 & 28,7 & 28,1 & 27,6 & 29,5 & 28,4 \\
\hline Raakahiilihydraatit & 835,7 & 834,6 & 832,7 & 832,8 & 811,5 & 808,0 & 809,3 & 812,8 \\
\hline Tärkkelys ${ }^{1}$ & 620,0 & 610,8 & 617,1 & 589,8 & 603,6 & 605,8 & 593,7 & 598,1 \\
\hline Tärkkelys $^{2}$ & 600,7 & 556,7 & 560,8 & 369,4 & 560,1 & 513,6 & 621,6 & 456,9 \\
\hline NDF-kuitu & 242,8 & 236 & 246,3 & 212,3 & 218,7 & 218,9 & 217,1 & 220,7 \\
\hline ADF-kuitu & 69,2 & 71,3 & 70,8 & 70,8 & 65,6 & 64,3 & 68,7 & 75,7 \\
\hline \multicolumn{9}{|l|}{ ß-glukaanit } \\
\hline Kokonais & 30,47 & 30,55 & 30,16 & 29,57 & 29,46 & 30,77 & 29,62 & 29,82 \\
\hline Liukoiset & 21,09 & 28,43 & 16,35 & 28,34 & 9,58 & 22,67 & 12,57 & 25,78 \\
\hline Liukenemattomat & 9,37 & 2,13 & 13,82 & 1,23 & 19,89 & 8,1 & 17,04 & 4,04 \\
\hline $\mathrm{pH}$ & & & & & 6,63 & 5,38 & 5,37 & 5,39 \\
\hline Muurahaishappo & & & & & 3,30 & 3,41 & 4,05 & 4,08 \\
\hline Etikkahappo & & & & & 1,43 & 0,13 & 1,45 & 1,77 \\
\hline Voihappo & & & & & 0,05 & 0,05 & 0,06 & 0,35 \\
\hline Maitohappo & & & & & 0,11 & 0,36 & 0 & 0,50 \\
\hline $\begin{array}{l}\text { Veden sidontakyky, } \\
\mathrm{g} / \mathrm{g} \mathrm{ka}\end{array}$ & 1,996 & 1,699 & 4,155 & 2,513 & 2,324 & 2,065 & 4,643 & 2,576 \\
\hline \multicolumn{9}{|l|}{ Aminohapot } \\
\hline Lysiini & 4,05 & & 4,37 & & 4,32 & & 4,23 & \\
\hline Metioniini & 1,9 & & 1,87 & & 2,15 & & 2,13 & \\
\hline Kystiini & 2,45 & & 2,43 & & 2,76 & & 2,71 & \\
\hline Treoniini & 3,72 & & 3,6 & & 4,1 & & 3,93 & \\
\hline
\end{tabular}

1. Tärkkelysmääritys ilman sokeriuuttoa.

2. Tärkkelysmääritys sokeriuutolla. 
SUOMEN MAATALOUSTIETEELLISEN SEURAN TIEDOTE NRO 21

Taulukko 5. Murskesäilönnän, kypsytyksen ja entsyymikäsittelyn vaikutus ohrapohjaisen rehun sulavuuteen siniketuilla (LS-keskiarvot).

\begin{tabular}{|c|c|c|c|c|c|c|c|c|c|c|c|c|c|c|c|}
\hline Ryhmä & 1 & 2 & 3 & 4 & 5 & 6 & 7 & 8 & SEM & $\mathrm{C} 1$ & $\mathrm{C} 2$ & $\mathrm{C} 3$ & $\mathrm{C} 4$ & $\mathrm{C} 5$ & C6 \\
\hline Vilja & $\mathrm{K}$ & $\mathrm{K}$ & $\mathrm{K}$ & $\mathrm{K}$ & $\mathrm{M}$ & $\mathrm{M}$ & $\mathrm{M}$ & $\mathrm{M}$ & & & & & & & \\
\hline Kypsennys & - & - & + & + & - & - & + & + & & & & & & & \\
\hline Entsyymi & - & + & - & + & - & + & - & + & & & & & & & \\
\hline \multicolumn{16}{|l|}{ Sulavuus, \% } \\
\hline Kuiva-aine & 54,7 & 56,5 & 66,0 & 69,9 & 49,3 & 55,7 & 63,5 & 69,3 & 0,49 & $* * *$ & $* * *$ & $* * *$ & * & $* * *$ & $\mathrm{~ns}$ \\
\hline Orgaaninen aine & 56,1 & 57,5 & 67,8 & 71,9 & 50,3 & 57,1 & 65,6 & 71,6 & 0,50 & $* * *$ & $* * *$ & $* * *$ & $*$ & $* * *$ & $\mathrm{~ns}$ \\
\hline Tuhka & 27,2 & 38,9 & 35,4 & 34,5 & 32,8 & 30,9 & 23,6 & 25,0 & 0,96 & $* * *$ & $* * *$ & $* *$ & $* * *$ & $* * *$ & $* *$ \\
\hline Raakavalkuainen & 69,4 & 71,0 & 69,5 & 73,0 & 66,9 & 70,0 & 70,8 & 74,2 & 0,59 & ns & $* * *$ & $* * *$ & $* * *$ & ns & $\mathrm{ns}$ \\
\hline Raakarasva & 91,2 & 91,7 & 89,8 & 91,2 & 89,2 & 91,0 & 89,2 & 91,4 & 0,20 & $* * *$ & $*$ & $* * *$ & $* * *$ & $* * *$ & $*$ \\
\hline Raakahiilihydr. & 38,8 & 41,5 & 60,2 & 65,3 & 31,6 & 38,9 & 55,7 & 63,7 & 0,75 & $* * *$ & $* * *$ & $* * *$ & $\mathrm{o}$ & $* * *$ & ns \\
\hline NDF-kuitu & 17,6 & 17,1 & 22,6 & 18,2 & 24,4 & 19,4 & 11,6 & 6,6 & 1,30 & $* * *$ & $* * *$ & $* * *$ & $* * *$ & ns & $\mathrm{ns}$ \\
\hline Tärkkelys & 48,4 & 47,9 & 75,9 & 82,8 & 36,1 & 41,9 & 72,6 & 82,7 & 0,90 & $* * *$ & $* * *$ & $* * *$ & $* * *$ & $* * *$ & $* * *$ \\
\hline $\mathrm{ME}, \mathrm{MJ} / \mathrm{kg} \mathrm{ka}$ & 13,44 & 13,33 & 14,95 & 15,75 & 11,91 & 13,55 & 14,76 & 15,90 & & & & & & & \\
\hline Päiväkasvu, g/pv & 23,8 & 14,4 & 29,8 & 50,0 & 10,5 & 17,0 & 39,9 & 60,9 & 4,15 & $\mathrm{~ns}$ & $* * *$ & $* *$ & $* *$ & ns & $* * *$ \\
\hline
\end{tabular}

Vilja: K=kuivattu ohra. M=murskesäilötty ohra; Kypsennnys: - = raaka. + = keitto; Entsyymi: - = ei entsyymikäsittelyä. + = ohran entsyymikäsittely.

$\mathrm{C} 1=$ kuivattu vs murskesäilötty ohra; $\mathrm{C} 2=$ raaka ohra vs keitetty ohra; $\mathrm{C} 3=$ ohran entsyymikäsittely; $\mathrm{C} 4=$ yhdysvaikutus $\mathrm{C} 1 * \mathrm{C} 2 ; \mathrm{C} 5=$ yhdysvaikutus $\mathrm{C} 1 * \mathrm{C} 3$; $\mathrm{C} 6=\mathrm{yhdysvaikutus}$ $\mathrm{C} 2 * \mathrm{C} 3$. 